\begin{tabular}{cc|c}
\hline Tar. Bil. Der. & Journal of Agricultural Sciences \\
& $\begin{array}{c}\text { Dergi web sayfası: } \\
\text { www.agri.ankara.edu.tr/dergi }\end{array}$ & Journal homepage: \\
& www.agri.ankara.edu.tr/journal
\end{tabular}

\title{
Selection of Suitable Sites for Small Ruminant Production Using Remote Sensing and the Geographic Information System
}

\author{
Esin DERİ ${ }^{\mathrm{a}}$, Halil Baki ÜNAL ${ }^{\mathrm{a}}$ \\ ${ }^{a}$ Ege University, Faculty of Agriculture, Department of Farm Structures and Irrigation, İzmir, TURKEY
}

\section{ARTICLE INFO}

Research Article

DOI: 10.15832 /ankutbd.447747

Corresponding Author: Esin DERİ, E-mail: esinderi@hotmail.com, Tel: +90 (535) 1090408

Received: 04 January 2016, Received in Revised Form: 19 February 2016, Accepted: 20 February 2016

\begin{abstract}
The aim of this study was to determine the most suitable areas for small ruminant production in the Karaburun area in Izmir province, Turkey. To this purpose, an inquiry model was first developed using remote sensing and a geographic information system. In developing the model, legal and technical factors were taken into consideration, and eight evaluation criteria (distance from settled areas, distance from lakes or similar water sources, distance from protected water catchment basins, distance from wind energy generators, distance from irrigation and drainage canals, slope, aspect-direction of slope-and land use class) and three evaluation classes in relation to these criteria (suitable, conditionally suitable and unsuitable) were planned. Later, the model was used to test the suitability of the study area in general and five sample farms in that area for suitability. According to all of the criteria of evaluation, $3.54 \%$ of the $42,707.15$ ha study area was found to be suitable for small ruminant production, $2.78 \%$ was conditionally suitable, and $93.60 \%$ was unsuitable. As for the five sample farms in the study area, none of them was found to be suitable according to all of the evaluation criteria. In addition, suggestions were made for the functionality and effectiveness in use of the geography information inquiry models used in the choice of places for small ruminant production.
\end{abstract}

Keywords: Remote sensing; Geographic information system; Small ruminant production; Farm location; Karaburun

\section{Uzaktan Algılama ve Coğrafi Bilgi Sistemi Kullanılarak Küçükbaş Hayvancılık İşletmeleri İçin Uygun Yerlerin Seçimi}

\section{ESER BILLGISİ}

Araştırma Makalesi

Sorumlu Yazar: Esin DERI, E-posta: esinderi@hotmail.com, Tel: +90 (535) 1090408

Geliş Tarihi: 04 Ocak 2016, Düzeltmelerin Gelişi: 19 Şubat 2016, Kabul: 20 Şubat 2016

\section{ÖZET}

Bu araştırmada, İzmir ili Karaburun yöresinde küçükbaş hayvancılık işletmeleri için en uygun alanların belirlenmesi amaçlanmıştır. $\mathrm{Bu}$ amaçla, ilk olarak uzaktan algılama ve coğrafi bilgi sistemi kullanılarak bir sorgu modeli geliştirilmiştir. Modelin geliştirilmesinde, küçükbaş hayvancılık işletmeleri için uygun yer seçimine ilişkin yasal ve teknik esaslar dikkate alınarak, sekiz değerlendirme ölçütü (yerleşim yerlerine uzaklık, göl ve benzeri su kaynaklarına 
uzaklık, su havzaları koruma alanlarına uzaklık, rüzgar enerji santrallerine uzaklık, sulama ve drenaj kanallarına uzaklık, eğim, bakı ve arazi kullanım sınıfi) ve bu ölçütlere ilişkin üç değerlendirme sınıfı (uygun, koşullu uygun ve uygun değil) öngörülmüştür. Sonra, geliştirilen sorgu modeli ile araştırma alanı genelinin ve bu alan içerisindeki mevcut beş örnek işletmenin uygunluğu sorgulanmıştır. Tüm değerlendirme ölçütlerine göre, 42,707.15 ha'lık araştırma alanının \% 3.54'ünün küçükbaş hayvancılığın yapılmasına “uygun”, \% 2.78'inin “koşullu uygun” ve \% 93.60'ının ise "uygun olmayan" alanlar olduğu belirlenmiştir. Araştırma alanındaki mevcut beş örnek işletmenin yerlerinin ise tüm değerlendirme ölçütlerine göre hiçbirinin uygun olmadığı belirlenmiştir. Ayrıca araştırmada, hayvancılık işletmesi yerlerinin seçiminde kullanılacak coğrafi bilgi sistemi sorgu modellerinin işlevselliğinin ve kullanım etkinliğinin arttırılmasına yönelik öneriler sunulmuştur.

Anahtar Kelimeler: Uzaktan algılama; Coğrafi bilgi sistemi; Küçükbaş hayvancılık; İşletme yeri; Karaburun

(C) Ankara Üniversitesi Ziraat Fakültesi

\section{Introduction}

As the world's population increases rapidly and industrialisation causes a decrease in the quality of water, air and soil, it becomes increasingly difficult to meet the needs of large societies for food. Thus, in order to provide this increasing population with sufficient and balanced nutrition, developing the animal husbandry sector has become of strategic importance for all countries of the world (Ünal et al 2013). In the rapidly developing animal husbandry sector, there has been an increase in the number of animals on farms and a corresponding increase in waste from those farms, creating large problems for the environment. If necessary measures are not taken, it is unavoidable that the waste originating from animal production activities will pollute the environment, the groundwater, and surface water (Ongley 1996; Mutlu 1999; Karaman 2006; Çayır et al 2012).

Although Turkey has more small ruminants than most countries in the world, the amount of yield is low compared with more developed countries. One of the main reasons for this is that the choice of location and the design of shelters on livestock farms are not appropriate. Thus recent scientific studies of livestock farming enterprises have pointed to mistaken practices with regard to the location of animal shelters and shelter construction (Kaymakçı et al 2005; Alkan et al 2013). Also, there is no accepted decision mechanism in Turkey for the choice of location of livestock farming enterprises, and therefore this choice is left to the farmers' own knowledge and physical resources. In animal production, the choice of location for production with optimum profit and minimum environmental damage is of the utmost importance (Karaman 2006; Boyac1 et al 2011). However, scientific studies in this country of choice of location for animal production activities are extremely limited (Çiçek \& Şenkul 2006).

Many studies have been conducted on the analysis by the Geography Information System (GIS) of spatial data such as crop cover, slope and aspect obtained by the remote sensing (RS) technique (Aranoff 1989; Yomralıoğlu 2000; Kurucu et al 2004; Alsancak 2005; Daşdemir 2006; Demirkesen 2007; Susam \& Karaman 2007; Töreyen et al 2011; Cengiz et al 2013). At the same time, inquiry models to determine suitable locations for animal production have been developed, and are starting to be used along with RS and GIS techniques (Zeng \& Hong 2008; Beyazit et al 2011; Terfa \& Suryabhagavan 2015).

The objective of this study was to determine the most suitable locations in the Karaburun, Izmir area for small ruminant production from a legal and technical standpoint with the help of RS and GIS techniques.

\section{Material and Methods}

\subsection{Determination of the research area}

Choice of location in small ruminant production is of great importance according to the type of animal being kept, especially for hair goats. In selecting the study area, account was taken of the numbers 
of different goat breeds being kept in the various districts of Izmir province, in the Aegean Region of Turkey. According to statistics for the year 2014, the number of hair goats, 35,600 , constituted $15.1 \%$ of the total number of goats $(235,834$ hair and angora goats), giving it greater potential than other districts in the province (TÜIK 2014). In addition, a variety of spatial factors affect animal production in this area. For this reason, Karaburun district in the province of Izmir was seen to be suitable for this research. The location of the research area is shown in Figure 1.
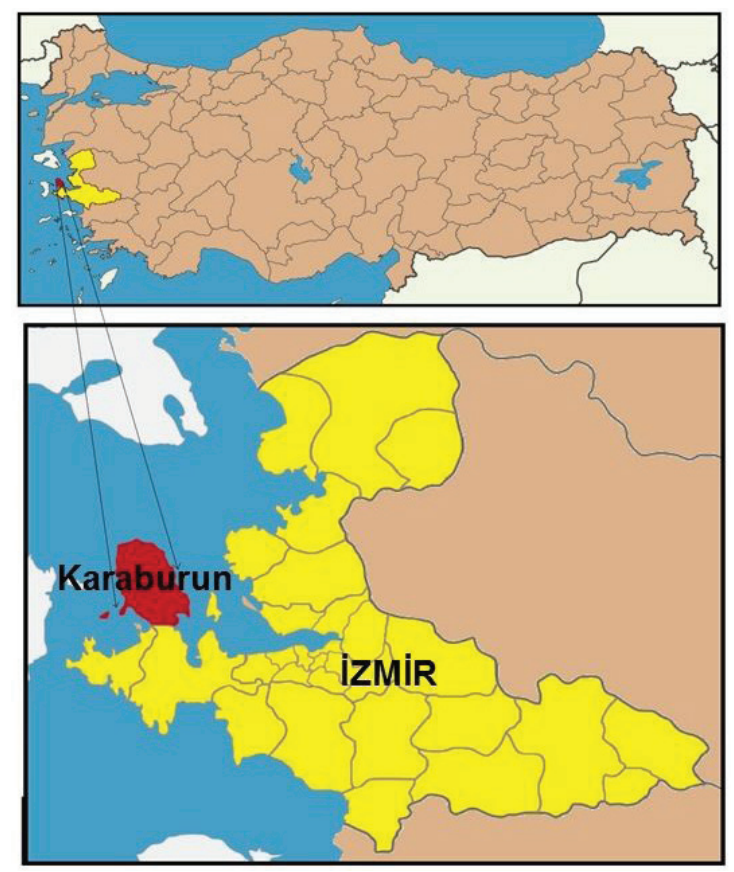

Figure 1- Location of the study area

Şekil 1-Araştırma alanının konumu
Subsequently, five farms, which were the subject of a study by Ünal et al (2015) in the Karaburun area, were considered for analysis of the suitability of location of current small ruminant production using the GIS inquiry model which was developed. These farms were registered with the Izmir Sheep and Goat Breeders' Association, and had 100 or more animals. The coordinates of these sample farms are given in Table 1.

Table 1- Coordinates of the locations of sample farms in the study area (Ünal et al 2015)

Çizelge 1- Araştırma alanindaki örnek işletmelerin konumlarına ilişkin koordinat değerleri (Ünal et al 2015)

\begin{tabular}{|c|c|c|}
\hline $\begin{array}{c}\text { Sample farm } \\
\text { no }\end{array}$ & Longitude & Latitude \\
\hline 1 & $26^{\circ} 22^{\prime} 09.04 " \mathrm{E}$ & $38^{\circ} 39^{\prime} 18.12 " \mathrm{~N}$ \\
\hline 2 & $26^{\circ} 21 ' 38.98^{\prime \prime} \mathrm{E}$ & $38^{\circ} 38^{\prime} 31.55^{\prime \prime} \mathrm{N}$ \\
\hline 3 & $26^{\circ} 23,30.26^{\prime \prime} \mathrm{E}$ & $38^{\circ} 33^{\prime} 29.15^{\prime \prime} \mathrm{N}$ \\
\hline 4 & $26^{\circ} 23^{\prime} 33.65^{\prime \prime} \mathrm{E}$ & $38^{\circ} 31 ' 31.13 ” \mathrm{~N}$ \\
\hline 5 & $26^{\circ} 26^{\prime} 39.61 " \mathrm{E}$ & $38^{\circ} 28^{\prime} 40.89 \prime \mathrm{N}$ \\
\hline
\end{tabular}

Karaburun district, which formed the study area, is located in the northern part of the Urla peninsula, which extends into the Aegean Sea. It is surrounded on the west, north and east by the sea, with the district of Urla to the south (Karaburun Kaymakamlığ1 2015). Karaburun district area covers an area of 42,707.15 ha (İzmir İl Özel İdaresi 2011).

Table 2 shows the map data used in the development of the model, which consisted of the type and format of data, the coordinate system and the source of the data. Also, safety strips were created for 14 wind turbine generators planned in the study area, and the coordinates of these generators were used as material (ARİ-ES 2015).

Table 2- Map data used in the study

Çizelge 2- Araştırmada kullanılan harita verilerinin tanımlanması

\begin{tabular}{llll}
\hline Data & Data source & Data type and format & Coordinate system \\
\hline $\begin{array}{l}\text { Slope map } \\
\text { Land use map }\end{array}$ & İzmir İl Özel İdaresi & Numerical/Shape file & $\begin{array}{l}\text { UTM, ED50, } \\
\text { 6 degrees }\end{array}$ \\
$\begin{array}{l}\text { Map of land classification according to law } \\
\text { No. } 5403 \text { on soil protection and land use }\end{array}$ & & & \\
\hline $\begin{array}{l}\text { DEM map, (ASTER GDM Version 1, 30 } \\
\text { metre resolution) }\end{array}$ & $\begin{array}{l}\text { Japan Space System } \\
(2015)\end{array}$ & Raster/GeoTIFF & WGS84 \\
\hline
\end{tabular}




\subsection{Numerical data for the research area}

Numerical data for the research area were taken as ED 1950 UTM $35 \mathrm{~N}$ conversions for the map projection system, and therefore there was no need for a separate correction of coordinates. In order to obtain data on the aspect of land in the study area, raster data of ASTER GDEM Version 1, was used (Japan Space System 2015). This raster data is provided in Geo TIFF format and with WGS84 projection, and so the coordinate system was converted to ED 1950 UTM $35 \mathrm{~N}$ and cell size was corrected to $30 \times 30$. After that, aspect data were obtained using the DEM map on the program
ArcGIS10.2.2 created according to these data and taking the borders of Karaburun district as a base. Slope data were obtained from a 1/100,000 scale shape file map previously created for the study area (İzmir İl Özel İdaresi 2011).

\subsection{Predicted evaluation criteria in the inquiry into suitable choice of location}

In this study, eight different evaluation criteria and three different evaluation classes were planned, taking account of legislation on the choice of suitable locations for small ruminant production and information in the literature. These are defined in Table 3.

Table 3- Evaluation criteria and categories planned in the inquiry for choice of suitable location for small Ruminant farms

Çizelge 3- Küçükbaş hayvancılık işletmeleri için uygun yer seçimi sorgulamasında öngörülen değerlendirme ölçütleri ve sınıfları

\begin{tabular}{|c|c|c|c|c|c|}
\hline \multirow[b]{2}{*}{ Evaluation criteria } & \multirow[b]{2}{*}{ Values for criteria } & \multicolumn{3}{|c|}{ Evaluation classes } & \multirow[b]{2}{*}{ References } \\
\hline & & Unsuitable & $\begin{array}{l}\text { Conditionally } \\
\text { suitable* }\end{array}$ & Suitable & \\
\hline $\begin{array}{l}\text { 1) Distance from } \\
\text { inhabited areas }\end{array}$ & $>500 \mathrm{~m}$ & $<500 \mathrm{~m}$ & $500-1000 \mathrm{~m}$ & $>1000 \mathrm{~m}$ & $\begin{array}{l}\text { SB (2000); Çevre } \\
\text { Bakanlığı (1986); } \\
\text { Tarım ve Köyişleri } \\
\text { Bakanlığı (2006) }\end{array}$ \\
\hline $\begin{array}{l}\text { 2) Distance from } \\
\text { water sources }\end{array}$ & $>300 \mathrm{~m}$ & $<300 \mathrm{~m}$ & $300-600 \mathrm{~m}$ & $>600 \mathrm{~m}$ & Olgun (2011) \\
\hline $\begin{array}{l}\text { 3) Distance from } \\
\text { irrigation and } \\
\text { drainage canals }\end{array}$ & $>100 \mathrm{~m}$ & $<100 \mathrm{~m}$ & - & $\geq 100 \mathrm{~m}$ & Olgun (2011) \\
\hline $\begin{array}{l}\text { 4) Distance from } \\
\text { wind turbine safety } \\
\text { strips }\end{array}$ & $\begin{array}{l}\text { Distance of } \\
\text { specified safety } \\
\text { strip }\end{array}$ & $<300 \mathrm{~m}$ & - & $\geq 300 \mathrm{~m}$ & ETKB (2015) \\
\hline $\begin{array}{l}\text { 5) Distance from } \\
\text { water catchment } \\
\text { basin protected areas }\end{array}$ & $\begin{array}{l}\text { Specified } \\
\text { distances of } \\
\text { defined protection } \\
\text { areas }\end{array}$ & $\begin{array}{l}\text { Inside definite, } \\
\text { short-distance } \\
\text { or medium- } \\
\text { distance } \\
\text { protected areas }\end{array}$ & $\begin{array}{l}\text { Inside long- } \\
\text { distance } \\
\text { protected areas }\end{array}$ & $\begin{array}{l}\text { Outside } \\
\text { long- } \\
\text { distance } \\
\text { protected } \\
\text { areas } \\
\end{array}$ & İZSU (2002) \\
\hline 6) Slope & $2-6 \%$ & $>60 \%$ & $30-60 \%$ & $<30 \%$ & $\begin{array}{l}\text { MWPS (1982); } \\
\text { Olgun (2011) }\end{array}$ \\
\hline 7) Aspect & South or southeast & $\begin{array}{l}\text { North, } \\
\text { ortheast, east, } \\
\text { west, orthwest }\end{array}$ & - & $\begin{array}{l}\text { South, } \\
\text { southeast, } \\
\text { southwest }\end{array}$ & Olgun (2011) \\
\hline 8) Land use class & $\begin{array}{l}\text { Land not suitable } \\
\text { for agriculture }\end{array}$ & $\begin{array}{l}\text { Land suitable } \\
\text { for agriculture }\end{array}$ & - & $\begin{array}{l}\text { Marginal } \\
\text { agricultural } \\
\text { land }\end{array}$ & $\begin{array}{l}\text { Şengonca et al (2009); } \\
\text { İzmir İl Özel İdaresi } \\
(2011)\end{array}$ \\
\hline
\end{tabular}

*, on condition of extra measures being taken 


\subsection{Development of the inquiry model}

An inquiry model was developed using GIS on data derived from images provided by RS with the aim of determining suitable locations where small ruminant rearing could be practiced in the study area. The program ArcGIS10.2.2 was used for all operations at this stage. In the inquiry according to the first five planned evaluation criteria (distance from inhabited areas, distance from lakes or similar water sources, distance from protected water catchment basins, distance from wind energy generators and distance from irrigation and drainage canals), a buffer zone analysis was made according to the evaluation classes of these criteria. The inquiry according to the other three evaluation criteria (slope, aspect and land use class) was made according to the evaluation classes in the layers with the help of the "Select" tool. In this way the eight new data layers obtained were joined and converted to a single layer. Later, an inquiry of the farm location was made according to the evaluation classes using "Query builder" according to single layer analysis logic, and the results were interpreted by mapping (Töreyen et al 2011).

\section{Results and Discussion}

\subsection{The inquiry model}

Figure 2 shows layer and attribute information of the inquiry model which was developed concerning the eight evaluation criteria (model layers) and the three evaluation classes relating to these criteria (attributes of the model layers) taking account of the legislation and technical basis for the choice of a suitable location for small ruminant rearing in the study area. In this model, layers were created according to environmental factors. However, it is possible to carry out this enquiry according to more layers including socio-economic factors (Terfa \& Suryabhagavan 2015).

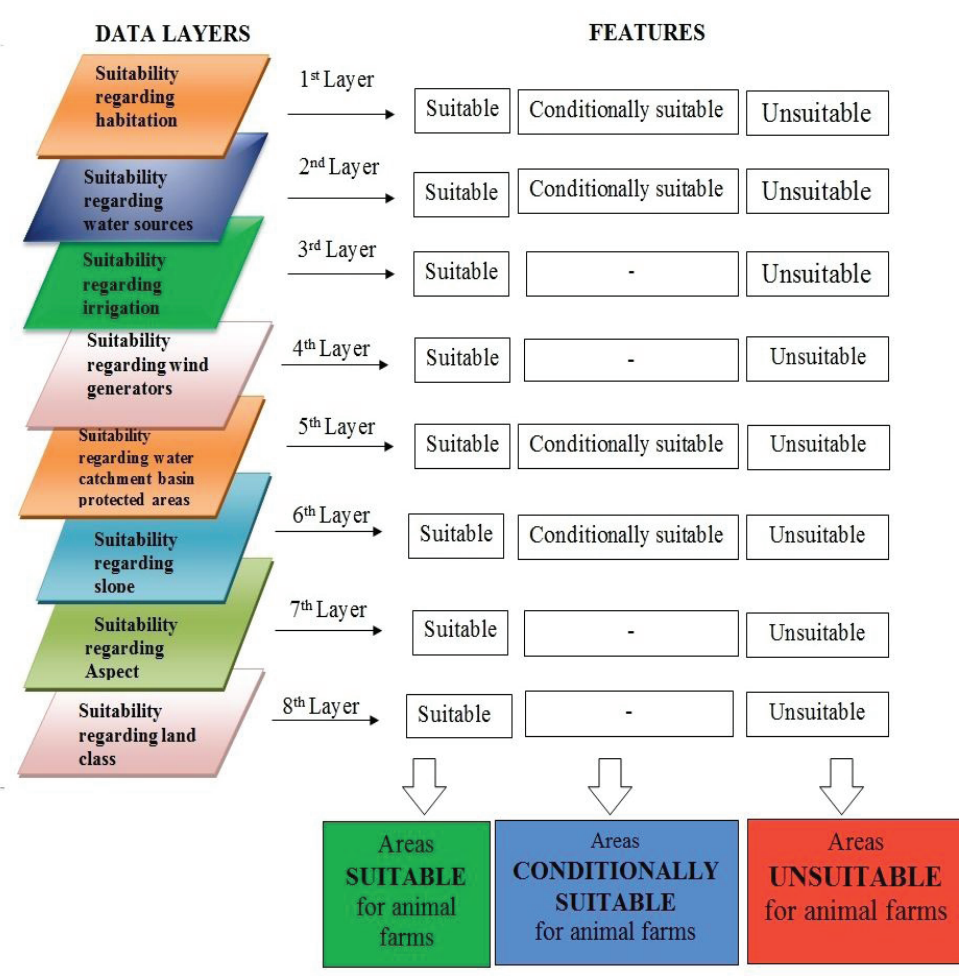

Figure 2- The inquiry model

Şekil 2- Geliştirilen sorgu modeli 


\subsection{Suitability according to evaluation criteria in the research area}

Table 4 gives the spatial and proportional distribution of the suitability of each evaluation criterion according to the suitability maps produced. It was seen that according to the land use class criterion $78.4 \%$ of the study area was unsuitable for small ruminant rearing, and $65 \%$ was unsuitable because of the criterion of aspect. Also, according to the criterion of inhabited areas, $12.1 \%$ of the study area was unsuitable for small ruminant production (Table 4). Sustainable animal farming which does not damage the environment does not seem possible in areas which were unsuitable according to the laws which were taken as a basis in this study, or on a scientific basis (MWPS 1982; Ongley 1996; SB 2000; Olgun 2011).

\subsection{Suitability of the study area according to all evaluation criteria}

The model which was developed was questioned as to the suitability of the study area for small ruminant production according to the eight evaluation criteria as a whole, and the results are given in Figure 3. The suitability of the study area for small ruminant production according to this suitability map is shown in Figure 4 along with spatial and proportional distribution. It was found that $3.54 \%$ of the $42,707.15$ ha study area was classed as suitable according to the total of the evaluation criteria, $2.78 \%$ as conditionally suitable, and $93.68 \%$ as unsuitable (Figure 3-4).

Setting up small ruminant farms in unsuitable areas will have a negative effect on inhabited areas, water sources, water storage basins and irrigated areas. This will threaten environmental cleanliness and hygiene, as well as human health. In addition, the land use classification of these areas and the land slope and aspect are not suitable for these farm structures (shelters and service structures). This will cause damage to crop production areas, the structures will increase the cost of construction, and the shelter will make the inspection of internal and external conditions difficult (MWPS 1982; Ongley 1996; Zeng \& Hong 2008; Olgun 2011).

Table 4- Suitability of the study area for small ruminant production according to the planned evaluation criteria

Çizelge 4- Araştırma alanının öngörülen değerlendirme ölçütlerine göre küçükbaş hayvancılık işletmeleri için uygunluk durumu

\begin{tabular}{|c|c|c|c|c|c|c|}
\hline \multirow{3}{*}{ Evaluation criteria } & \multicolumn{6}{|c|}{ Evaluation classes } \\
\hline & \multicolumn{2}{|l|}{ Unsuitable } & \multicolumn{2}{|c|}{ Conditionally suitable } & \multicolumn{2}{|l|}{ Suitable } \\
\hline & (ha) & $\%$ & (ha) & $\%$ & (ha) & $\%$ \\
\hline 1) Distance from inhabited areas & $5,151.34$ & 12.1 & $2,821.56$ & 6.6 & $34,734.24$ & 81.3 \\
\hline 2) Distance from water sources & 407.63 & 1 & 924.71 & 2.2 & $41,374.80$ & 96.9 \\
\hline $\begin{array}{l}\text { 3) Distance from irrigation and drainage } \\
\text { canals }\end{array}$ & 558.55 & 1.3 & $\begin{array}{c}\text { Not } \\
\text { applicable }\end{array}$ & - & $42,148.59$ & 98.7 \\
\hline 4) Distance from wind turbine safety strips & 359.64 & 0.8 & $\begin{array}{l}\text { Not } \\
\text { applicable }\end{array}$ & - & $42,347.50$ & 99.2 \\
\hline $\begin{array}{l}\text { 5) Distance from water catchment basin } \\
\text { protected areas }\end{array}$ & $4,731.28$ & 11.1 & $8,159.84$ & 19.1 & $29,815.87$ & 69.8 \\
\hline 6) Slope & $1,341.84$ & 3.1 & $4,854.59$ & 11.4 & $36,501.22$ & 85.5 \\
\hline 7) Aspect & $27,752.18$ & 65 & $\begin{array}{c}\text { Not } \\
\text { applicable }\end{array}$ & - & $14,954.97$ & 35.0 \\
\hline 8) Land use class & $33,492.21$ & 78.4 & $\begin{array}{c}\text { Not } \\
\text { applicable }\end{array}$ & - & $9,214.94$ & 21.6 \\
\hline
\end{tabular}




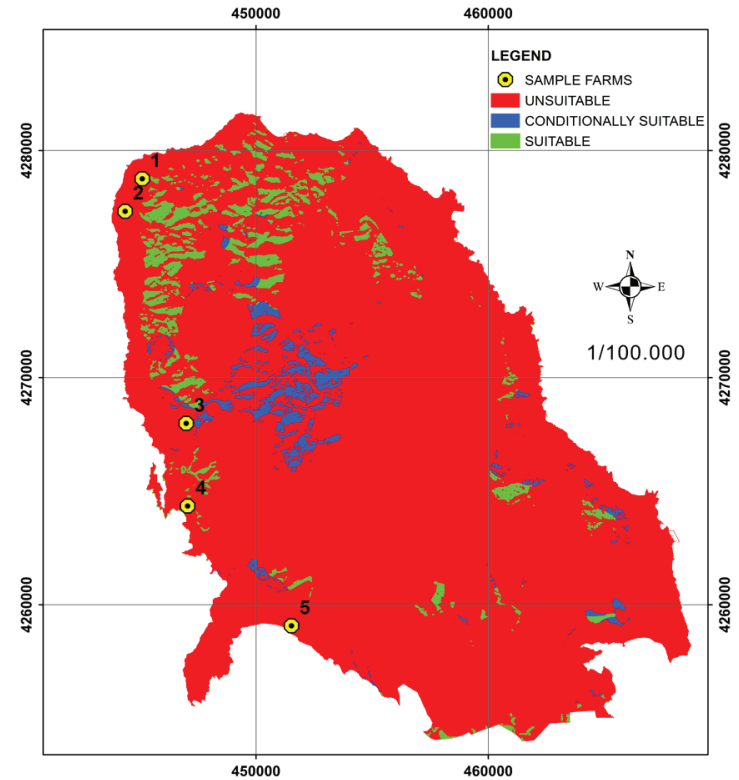

Figure 3- Map of the suitability of the study area for small ruminant rearing and location of existing sample farms

Şekil 3- Araştırma alanının küçükbaş hayvancılık işletmeleri için uygunluk haritası ve mevcut örnek işletmelerin konumu

\subsection{Suitability of the location of the sample farms in the research area}

The locations in the study area of the five sample small ruminant farms are shown in Figure 3. The

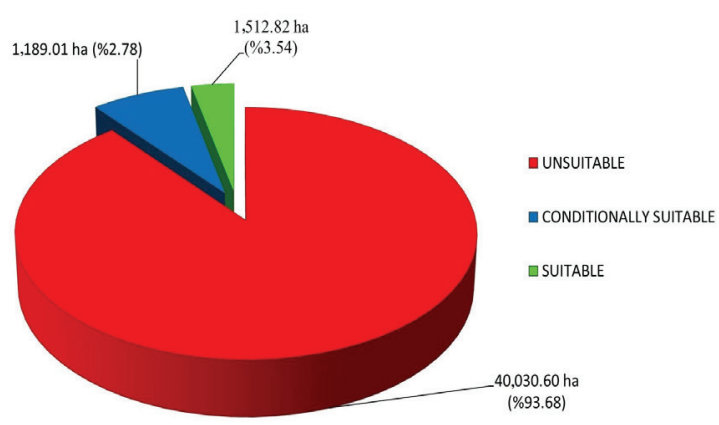

Figure 4- Spatial and proportional distribution of suitability for small ruminant rearing in the study area

Şekil 4- Araştırma alanının küçükbaş hayvancılık işletmeleri için uygunluk durumunun alansal ve oransal dă̆ılımı

locations of these farms were analyzed with the help of the inquiry model according to each evaluation criterion, and the results are given in Table 5.

When the locations of the sample farms were examined according to the totality of the eight evaluation criteria, it was found that none of the locations of the farms was suitable for small ruminant rearing (Figure 3). When they were examined according to the evaluation criteria individually, it was seen that there was no risk in any of the farms according to criteria $2-5$, but that

Table 5- Suitability of locations of sample farms in the study area according to each criterion individually Çizelge 5- Araştırma alanındaki mevcut örnek işletmelerin konumlarının her bir değerlendirme ölçütüne göre uygunluk durumu

\begin{tabular}{|c|c|c|c|c|c|c|c|c|c|c|c|c|c|c|c|c|c|c|c|}
\hline \multirow{3}{*}{ 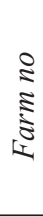 } & \multicolumn{19}{|c|}{ Evaluation criteria } \\
\hline & \multicolumn{2}{|c|}{$\begin{array}{l}\text { 1) Distance } \\
\text { from inhabited } \\
\text { areas }\end{array}$} & \multicolumn{3}{|c|}{$\begin{array}{l}\text { 2) Distance } \\
\text { from water } \\
\text { sources }\end{array}$} & \multicolumn{2}{|c|}{$\begin{array}{l}\text { 3) Distance } \\
\text { from irrigation } \\
\text { and drainage } \\
\text { canals }\end{array}$} & \multicolumn{2}{|c|}{$\begin{array}{l}\text { 4) Distance } \\
\text { from wind } \\
\text { turbine } \\
\text { safety strips }\end{array}$} & \multicolumn{3}{|c|}{$\begin{array}{l}\text { 5) Distance from } \\
\text { water catchment } \\
\text { basin protected } \\
\text { areas }\end{array}$} & \multicolumn{3}{|c|}{ 6) Slope } & \multicolumn{2}{|c|}{ 7) Aspect } & \multicolumn{2}{|c|}{$\begin{array}{l}\text { 8) Land } \\
\text { use clas }\end{array}$} \\
\hline & $N S \quad C S$ & $S$ & $N S$ & $C S$ & $S$ & $N S$ & $S$ & $N S$ & $S$ & $N S$ & $C S$ & $S$ & $N S$ & $C S$ & $S$ & $N S$ & $S$ & $N S$ & $S$ \\
\hline 1 & & $\mathrm{X}$ & & & $\mathrm{X}$ & & $\mathrm{x}$ & & $\mathrm{X}$ & & & $\mathrm{X}$ & & & $\mathrm{x}$ & & $\mathrm{X}$ & $\mathrm{x}$ & \\
\hline 2 & & $\mathrm{x}$ & & & $\mathrm{x}$ & & $\mathrm{x}$ & & $\mathrm{X}$ & & & $\mathrm{x}$ & & & $\mathrm{x}$ & $\mathrm{x}$ & & $\mathrm{x}$ & \\
\hline 3 & $\mathrm{x}$ & & & & $\mathrm{x}$ & & $\mathrm{x}$ & & $\mathrm{x}$ & & & $\mathrm{x}$ & & & $\mathrm{x}$ & $\mathrm{x}$ & & & $\mathrm{x}$ \\
\hline 4 & & $\mathrm{x}$ & & & $\mathrm{x}$ & & $\mathrm{x}$ & & $\mathrm{X}$ & & & $\mathrm{x}$ & & & $\mathrm{x}$ & $\mathrm{x}$ & & $\mathrm{x}$ & \\
\hline 5 & $\mathrm{x}$ & & & & $\mathrm{x}$ & & $\mathrm{x}$ & & $\mathrm{x}$ & & & $\mathrm{x}$ & & & $\mathrm{X}$ & $\mathrm{x}$ & & $\mathrm{x}$ & \\
\hline
\end{tabular}

NS, not suitable; CS, conditionally suitable; S, suitable 
according to criterion No. 1, the locations of farms No. 3 and 5 were not suitable. It was also seen that in general, the locations of the farms were not suitable according to criterion No. 7 (except for farm No. 1) and according to criterion No. 8 (except for farm No. 3) (Table 5). It has been reported that farms closer than $500 \mathrm{~m}$ to an inhabited area constitute a social and environmental health risk (SB 2000; Karaman 2006; Ünal et al 2013). It has been shown that farms on land with a northerly, north-westerly, westerly or easterly aspect will encounter difficulties in benefitting from winter sun and protection from summer sun and winter winds (Olgun 2011).

\section{Conclusions}

The present study was conducted to determine the most suitable areas for small ruminant production in the Karaburun district of Izmir province according to legal and technical evaluation criteria, and a GIS inquiry model was developed for locational data provided by the RS technique. Using this inquiry model, locations which were potentially suitable for small ruminant production were determined and the suitability of the locations of existing sample farms was analyzed. In farms established in the locations determined as suitable, it will be possible to conduct faming activities in a way which is better for animal welfare, prevents environmental damage and is more economic and sustainable.

The following recommendations are presented for the more successful choice of a suitable location for animal farming. In order to determine suitable locations where all kinds of animal farming can be practiced over wider areas, there is a need for scientific research to be conducted on the development of more inclusive evaluation criteria in the GIS model. Taking into account such factors as geological factors (mechanical and hydraulic characteristics of the ground, groundwater sources, etc), ownership, the characteristics of the breeds of animal reared or their environmental needs, sources of water and feed, market conditions, or economic factors such as building costs, there will be a wider range of inquiry possibilities with inquiry models which will be developed. In this way, it will provide very effective evaluation in the choice of suitable locations for farms. If the GIS models developed are used in setting up livestock farms, the new farms which are given permission to operate in suitable locations will be able to carry on their activities under more suitable conditions. In this way a contribution will be made to more productive, profitable and sustainable animal production. In order to increase the functionality and effectiveness in use of this type of inquiry model, it is of great importance that universities and public and private institutions should work together with farming organizations such as associations and cooperatives.

\section{References}

Alkan İ, Kandemir Ç, Ünal H B \& Taşkın T (2013). Küçükbaş yetiştiriciliğinde barınak yeri ve tipinin seçimi. Tarımsal Araştırma Yayım ve Ĕgitim Koordinasyonu (TAYEK), 2013 Yllı Hayvancılık Bölge Grup Toplantısı, 4-7 Kasım, Çanakkale, s. 1-9

Alsancak B (2005). Gediz havzasında iklim isteklerine göre farklı üzüm çeşitlerinin yetiştirilebileceği alanların belirlenmesi. Yüksek lisans tezi, Ege Üniversitesi Fen Bilimleri Enstitüsü (Basılmamış), İzmir

Aranoff S (1989). Geographical information systems: A management perspective. WDL Publications, Ottawa, Canada

ARİ-ES (2015). İzmir İli, Karaburun İlçesi Sarpıncık Rüzgâr Enerji Santrali Uygulama İmar Planı Açıklama Raporu. ARİ-ES Enerji Lojistik Merkezi, https://www.csb.gov.tr/db/izmir/editordosya/1000(3). pdf (Erişim tarihi: 22.05.2105)

Beyazıt I, Güler K, İnanoğlu G E \& Batuk F (2011). Hayvan barınağı yer seçiminde CBS'nin kullanımı. TMMOB Coğrafi Bilgi Sistemleri Kongresi, 31 Ekim04 Kasim, Antalya, s. 191-192

Boyacı S, Akyüz A \& Kükürtcü M (2011). Büyükbaş hayvan barınaklarında gübrenin yarattığı çevre kirliliği ve çözüm olanakları. Tarım Bilimleri Araştırma Dergisi 4(1): 49-55

Cengiz T, Akbulak C, Özcan H \& Baytekin H (2013). Gökçeada'da optimal arazi kullanımının belirlenmesi. Tartm Bilimleri Dergisi-Journal of Agricultural Sciences 19: 148-162

Çayır M, Atılgan A \& Öz H (2012). Büyükbaş hayvan barınaklarındaki gübrelikler ve su kaynaklarına 
olan durumlarının incelenmesi. Süleyman Demirel Üniversitesi Ziraat Fakültesi Dergisi 7(2): 1-9

Çevre Bakanlı̆̆ı (1986). Hava kalitesinin korunması yönetmeliği. 19269 sayılı Resmi Gazete, Sayı: 19269, Ankara

Çiçek H \& Şenkul Ç (2006). Coğrafi bilgi sistemleri ve hayvancılık sektöründe kullanım olanakları. Veteriner Hekimler Derneği Dergisi 77(4): 32-38

Daşdemir S (2006). Kimi tütün çeşitlerinin yetiştirilebilmesine uygun ekim alanlarının uzaktan algılama tekniği kullanılarak belirlenmesi ve bunların coğrafi bilgi sistemi yazılımları ortamında sorgulanması üzerine bir araştırma. Yüksek lisans tezi, Ege Üniversitesi Fen Bilimleri Enstitüsü (Basılmamış), İzmir

Demirkesen A C (2007). Günümüzde uzaktan algılama uygulamalarına genel bir bakış. TMMOB Harita ve Kadastro Mühendisleri Odası 11. Türkiye Harita Bilimsel ve Teknik Kurultayl, 2-6 Nisan, Ankara, s. 12

ETKB (2015). Rüzgar kaynağına dayalı elektrik üretimi başvurularının teknik değerlendirmesi hakkında yönetmelik taslağı. Enerji ve Tabii Enerji Kaynaklar Bakanlığı, Yenilenebilir Kaynaklar Genel Müdürlüğü http://www.yegm.gov.tr/yenilenebilir/YEKDEM. aspx (Erişim tarihi: 23.05.2015)

İzmir İl Özel İdaresi (2011). İzmir ili karaburun ilçesi arazi sınıflandırması projesi, İzmir İl Özel İdaresi (Basılmamış), İzmir

İZSU (2002). Su havzaları koruma yönetmeliği. İzmir Su ve Kanalizasyon İdaresi Genel Müdürlüğü, Tarih: 12.03.2002, Say1: 05/16 Yürürlük Tarihi: 01.04.2002, http://www.izsu.gov.tr/Pages/standartPage. aspx?id=70 (Erişim tarihi: 18.06.2014)

Japan Space System (2015). İzmir-Karaburun ilçesi DEM haritası. Retrieved in May, 23, 2015 from http://www. jspacesystems.or.jp/ersdac/GDEM/E/

Karaburun Kaymakamlığı (2015). Karaburun ilçesinin coğrafi yapısı. Karaburun Kaymakamlığ1, http:// www.karaburun.gov.tr/default_B0.aspx?content=195 (Erişim tarihi: 20.05.2015)

Karaman S (2006). Hayvansal üretimden kaynaklanan çevre sorunları ve çözüm olanakları. KSÜ Fen ve Mühendislik Dergisi 9(2): 133-139

Kaymakçı M, Eliçin A, Işın F, Taşkın T, Karaca O, Tuncel E, Ertuğrul M, Özder M, Güney O, Gürsoy O, Torun O, Altın T, Emsen H, Seymen S, Geren H, Odabaşı A \& Sönmez R (2005). Türkiye küçükbaş hayvan yetiştiriciliği üzerine teknik ve ekonomik yaklaşımlar.
Türkiye Ziraat Mühendisliği 6. Teknik Kongresi: 3-7 Ocak, Ankara, s. 707-726

Kurucu Y, Bolca M, Altınbaş U \& Esetlili T (2004). A study on the determination of the land use, elevation and slope of the land to the west of Söke by forming a digital elevation model and satellite image. Journal of Applied Sciences 4(4): 542-546

Mutlu A (1999). Adana ili çevresindeki hayvancılık tesislerinde ortaya çıkan atıkların yarattı̆̆1 çevre kirliliği üzerinde bir araştırma. Yüksek lisans tezi, Çukurova Üniversitesi Fen Bilimleri Enstitüsü (Basılmamış), Adana

MWPS (1982). Sheep housing and equipment handbook ( $3^{\text {rd }}$ Ed.). Midwest Plan Service, Ames, Iowa

Olgun M (2011). Tarımsal Yapılar. Ankara Üniversitesi Ziraat Fakültesi Yayınları: 1577, Ankara

Ongley E D (1996). Control of water pollution from agriculture. FAO Irrigation and Drainage: 55, Roma

SB (2000). Hayvan barınakları hakkında genelge. Sağlık Bakanlığı Temel Sağlık Hizmetleri Genel Müdürlüğü, http://www.istanbulsaglik.gov.tr/w/mev/ temel_saglik/hayvan_barinaklari.pdf (Erişim tarihi: 22.05.2015)

Susam T \& Karaman S (2007). Köy yerleşim alanlarının bazı özelliklerinin coğrafi bilgi sistemleri ile belirlenmesi: Tokat-Zile ilçesi örneği. Tekirdağ Ziraat Fakültesi Dergisi 4(2): 153-162

Şengonca M, Altan A \& Koşum N (2009). Hayvan yetiştirme ilkeleri. Ege Üniversitesi, Ziraat Fakültesi Yayınları: 550, Ders Kitab1: 184, İzmir

Tarım ve Köyişleri Bakanlığı (2006). Hayvancılık işletmelerinin kuruluş, çalışma, denetleme usul ve esaslarına dair yönetmelik. 26254 Sayılı Resmi Gazete, Ankara

Terfa B K \& Suryabhagavan K V (2015). Rangeland suitability evaluation for livestock productionusing remote sensingand GIS techniques in dire district, SouthernEthiopia. Global Journal of Science Frontier Research (H): Environment \& Earth Science, 15(1), Version 1.0, Type: DoubleBlind Peer Reviewed International Research Journal Publisher: Global Journals Inc. (USA) Online ISSN: 2249-4626 \& Print ISSN: 0975-5896

Töreyen G, Özdemir İ \& Kurt T (2011). ArcGIS 10 Desktop Uygulama Dokümanı. Esri Türkiye Eğitim Dokümanları, Sinan Ofset, Ankara, Türkiye 
TÜİK (2014). Hayvancilık istatistikleri veri tabanı. Yıllık Hayvan Sayısı ve Hayvansal Üretim 2014 Y1lı Hayvancılık İstatistikleri, http://tuikapp.tuik. gov.tr/hayvancilikapp/ hayvancilik.zul (Erişim tarihi: 03.03.2015)

Ünal H B, Taşkın T \& Alkan İ (2013). Hayvancılık işletmelerinde uygun yer seçimi. Tarım Türk Dergisi 39: $44-46$

Ünal H B, Taşkın T, Alçiçek A, Koşum N, Yılmaz H İ, Alkan İ \& Kandemir Ç (2015). İzmir yöresi koyun keçi yetiştiriciliğinde barındırma olanaklarının belirlenmesi ve uygun ağıl projelerinin geliştirilmesi.
Ege Üniversitesi Bilimsel Araştırma Proje Kesin Raporu (Proje No:2011-ZRF-056), Ege Üniversitesi Ziraat Fakültesi Tarımsal Yapılar ve Sulama Bölümü, İzmir

Yomralığlu T (2000). Cografi Bilgi Sistemleri Temel Kavramlar ve Uygulamalar. Akademi Kitatbevi, 2. Bask1, İstanbul

Zeng Y \& Hong H (2008). Selecting suitable sites for pig production using a raster GIS in Xinluo Watershed in Southeast China. The $2^{\text {nd }}$ International Conference on Bioinformatics and Biomedical (ICBBE 2008), May 16-18, Shanghai, China pp. 2813-2816 